\title{
Development of the embryo in some species of the genus Delphinium L.
}

\author{
HENRYK BABIS
}

Department of Biology, Higher Pedagogical School, Siedlce

(Received: January 2, 1976)

\begin{abstract}
In the 10 examined species of Delphinium all theoretically possible types of zygote division may be found - transverse, oblique and longitudinal. With these divisions is connected the peculiar characteristic mode of differentiation of the embryo body. Embryogenesis of two species, D. tricolor and D. cariopetalum, shows a number of regularities on the basis of which new types of embryo development in angiosperms may be distinguished. These types have been named Valerianad and Ranunculad.

Probably all the Delphinium species in which a longitudinal division of the zygote occurs are more primitive as regards embryonomic features than species in which zygote division is transverse or oblique.
\end{abstract}

\section{INTRODUCTION}

The development of the embryo in the family Ranunculaceae to which the genus Delphinum belongs is only well known in a few species. Most extensive investigations on the embryonomy of this family were performed by $\mathrm{S}$ o u è g e $\mathrm{s}(1910,1911,1912,1913)$. This author examined and described among others the development of the embryo in Myosurus minimus, Adonis autumnalis, A. aestivalis, Ficaria ranunculoides, Ranunculus acris, R. sceleratus, Anemone pulsatilla, A. japonica and Clematis recta. Short incomplete descriptions of embryo development in Ranunculaceae may be found in the works of other authors. Up till now within the genus Delphinium the embryo development has been investigated in $D$. consoli$d a(\mathrm{~L} y \mathrm{Th} \mathrm{i} \mathrm{B} \mathrm{a,} \mathrm{1962).} \mathrm{As} \mathrm{indicated} \mathrm{by} \mathrm{the} \mathrm{literature,} \mathrm{the} \mathrm{development}$ of the embryo in the family Ranunculaceae is not uniform.

The present author studied to date embryo development in 10 species of Delphinum. Embryogenesis of the 4 most characteristic species D. staphi- 
sagria L., D. tricolor Bernh., D. cardiopetalum D. C. and D. tatsinense Franch has been elaborated in detail, whereas in the 6 remaining species: D. elatum L., D. paniculatum Host., D. grandiflorum L., D. cashmirianum Royle. and D. zalil Aitch., D. nudicaule Terr. et Gray. the stage was investigated at which it was possible to establish the origin of the particular layers and their destination.

\section{MATERIAL AND METHODS}

The material of ovaries and ovules or prepared out embryos was fixed in chromium-aceto-formalin (CrAF 0.4-0.5-20.0). Sections were stained with Ehrlich's hematoxylin. In the analyses of microtome sections of essential importance was the plane along which the material was cut. Therefore a method was developed of embedding single ovules in paraffin in dependence on their plane of symmetry (B a b i s, 1973a).

\section{RESULTS}

The investigated Delphinium species may be classified to 4 embryonomic groups differing from one another essentially even in the earliest stages of embryonal development.

To the first embryonomic group belongs: D. staphisagria, D. elatum and D. paniculatum. In D. staphisagria (Plate Fig. $1-6$ ) the zygote divides as a rule transversely and so does the basal cell. The tetrad is 3-layered. In the 8-celled proembryo 4 homogeneous layers can be distinguished. From layer $q$ arise $p c o+p v t+1 / 2$ phy (cotyledones + growth tip of the embryo shoot $+1 / 2$ hypocotyl), from layer $m-1 / 2$ phy $(1 / 2$ of hypocotyl) arises, from layer $n-i c c+i e c+c o$ (initial cells of the central cylinder of the embryonal root + embryonal root cap) are formed and from layer $n^{1}-s$ (the suspensor). The embryo development in $D$. elatum and D. paniculatum is similar as in D. staphisagria. In these three species the proembryos are characterized by a radial symmetry on account of both the general habitus and the position of the first walls in early stages of development.

Development of the embryo in D. staphisagria, D. elatum and D. paniculatum may be classified to the Asterad type in J o han s en's classification (1950) or to period I of series A of the megaarchaetype III in the classification of $\mathrm{S}$ o u è g e $\mathrm{s}$ (1948).

To the embryonomic group II belong $D$. tricolor, D. grandiflorum, $D$. cashmirianum, D. zalil and D. nudicaule.

In D. tricolor (Plate, figs 7-13) the zygote divides as a rule more or less obliquely and so does the basal cell. The tetrad consists of two and one 
half layers. In the 8-cellular proembryo 3 layers can be distinguished: the homogeneous layer $q$ from arise which $p c o+p v t+1 / 2$ phy, the nonhomogeneous layer $m+n$ forming $1 / 2$ phy and the homogeneous layer $n^{1}$
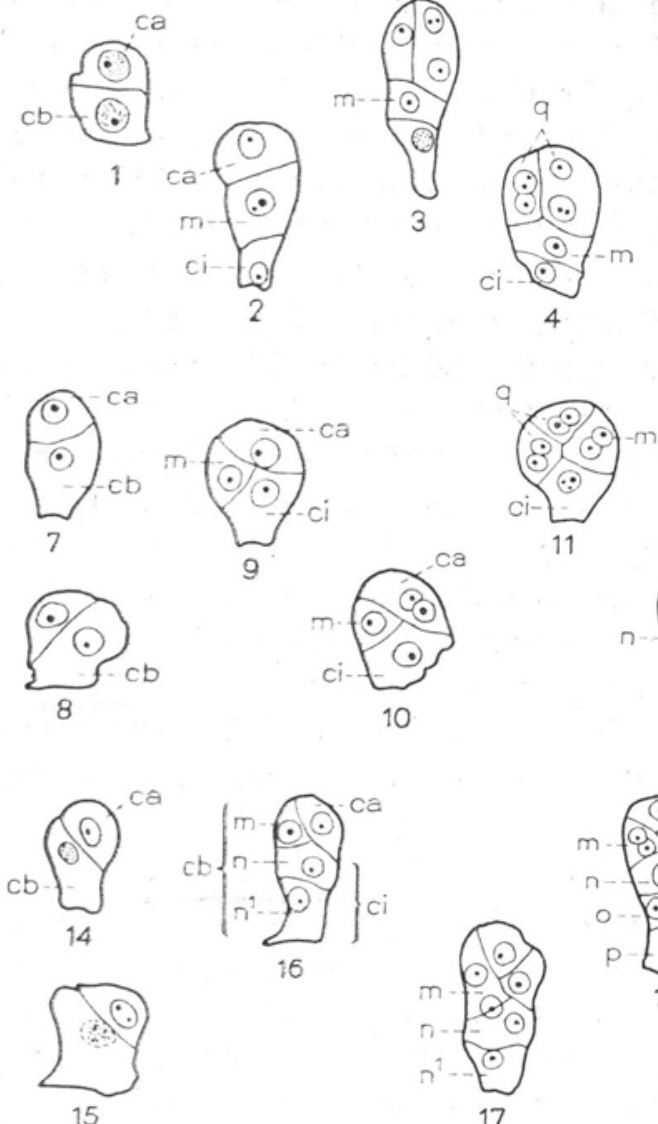

17
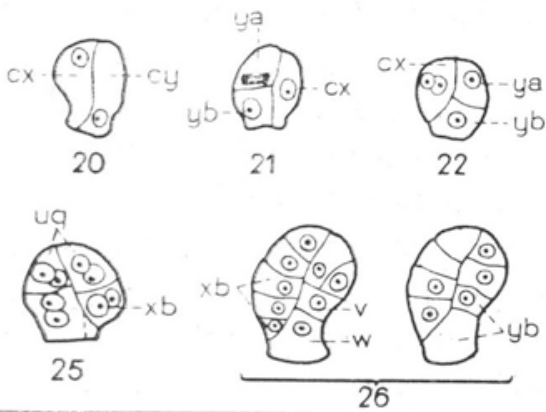
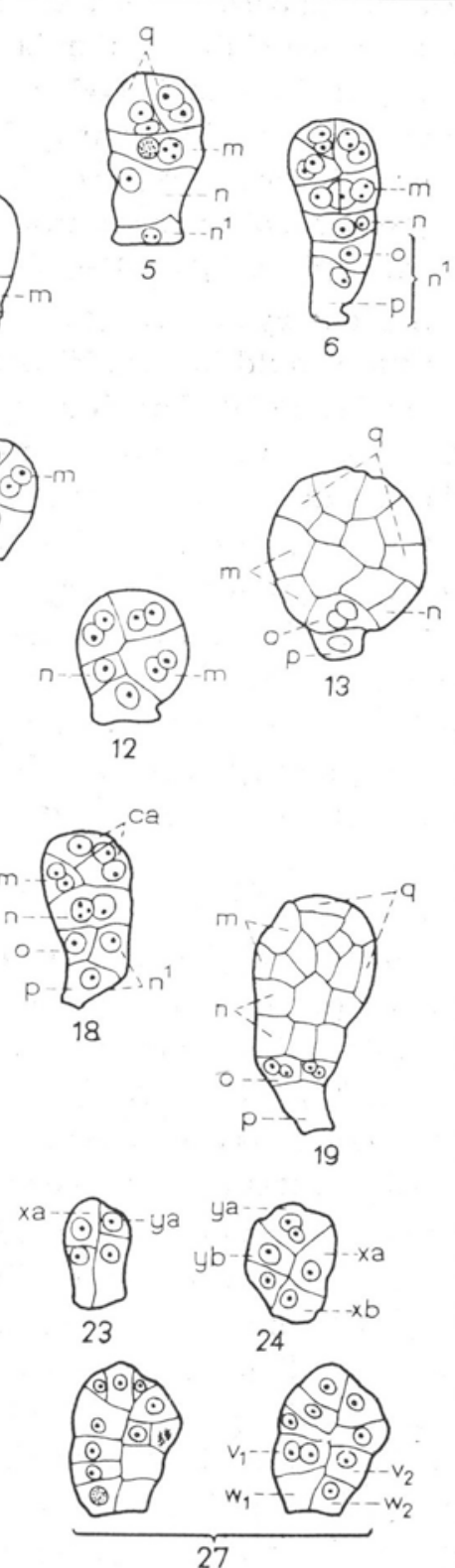

Initial stages of the development of the embryo in Delphinium

Figs 1-6. D. staphisagria, Figs 7-13. D. tricolor, Figs 14-19. D. cardiopetalum, Figs 20-27. D. tatsinense (Magn. ca $\times 250$ ) 
giving rise to $i c c+i e c+c o+s$. In these species the proembryo exhibits in early stages of development a dorso-ventral symmetry, both as regards general habitus and spatial position of first walls. The development of the embryo in $D$. tricolar is similar to that in D. grandiflorum, D. cashimirianum, D. zalil and D. nudicaule. Embryo genesis of the above named 5 Delphinium species shows a number of regularities on the basis of which a new type can be established in angiosperms. This type has been termed Valerianad. To the latter may be classified the forms described up till now in the literature as irregular and occurring in Lycopsis arvensis (S o u è g e s, 1938), Symphytum officinale ( $\mathrm{S}$ o u è g e s, 1941a) and Tilia platyphyllos ( $\mathrm{S}$ o u è g e s 1941b) and in several other species.

To the embryonic III group distinguished by the present author in Delphinium should be classified the embryo development in D. cariopetalum (B a b i s, 1966). The first zygote division in this species (Plate, Figs $14-19)$ is as a rule notably slanting, the basal cell also divides obliquely. Tetrads probably ocur only sporadically. The 8-celled proembryo comprises 4 layers. The proximal layer is nonhomogeneous and consists of $m+c a$ cells from which $p c o+p v t+1 / 2$ phy arise, the central layer $n$ is homogeneous and gives rise to $1 / 2$ phy, layer $o$ is also homogeneous and from it forms $i c c+i e c+c o$ and from the basal layer $p$ which also is homogeneous $s$ arises. A characteristic feature of this species in embryonal development is the fact that one cotyledone forms from derivatives of the apical cell $\mathrm{ca}$, and the second one from derivatives of the basal cell $c b$.

In $D$. cariopetalum the development of the apical cell is inhibited in relation to the basal one. The proembryos, in view of their shape, show a radial or dorso-ventral symmetry, whereas as regards the position of the first internal walls their symmetry is dorsoventral. The type of embryo development found in $D$. cardiopetalum has not so far been described in the literature. It is a new type in angiosperms, not included in embryonomic classifications and has been termed by the author Ranunculad type.

To the embryonomic group IV should be classified the embryo development in D. tatsinense (Plate, Figs $20-27$ ). The zygote divides as a rule almost longitudinally or vertically. The sister cells of the 2-celled proembryo usually divide transversally. The tetrad is generally two-layered, or sometimes the layers are not completely delineated. The 8-celled proembryo is usually two-layered. It is only in proembryos composed of a dozen cells or so that 3 layers can be distinguished: the proximal nonhomogeneous layer $x a+y a$ from which $p c o+p v t+1 / 2$ phy arise, the nonhomogeneous layer $x b+v$ from which $1 / 2$ phy forms and the homogeneous layer $w$ giving rise to $i c c+i e c+c o+s$. If the zygote divides longitudinally, the basal layer is also nonhomogeneous. The proembryos on account of their shape exhibit as a rule radial symmetry, whereas in 
relation to the spatial arrangement of the first walls their symmetry is dorso-ventral and radial.

The type of embryo development in $D$. tatsinense is similar to that in Scabiosa succisa and $S$. columbaria described by $\mathrm{S}$ o u è g e s $(1937,1957)$ and to that in Euphorbia rothiana described by S riva s t a v a (1952). It may be classified to the type Piperad of $\mathrm{J}$ oh a n s e n (1950).

The particular members of the embryo in D. tatsinense are denoted by new symbols (Plate, Figs. 20-27) on account of a number of inconsistencies in the so far used notations. After vertical or almost longitudinal division of the zygote, sister cells arise which have been denoted by the symboles $c x$ and $c y$. The symbol $c y$ marks the largest cell or the one dividing earlier and giving more derivatives. The smaller cell $c x$ after transverse division forms the upper cell $x a$ and the bottom one $x b$, the larger cell correspondingly forms $y a$ and $y b$. From the sister derivatives of the cells, $x a$ and $y a$, a 4-celled apical layer $u q$ is formed corresponding to the quadrants $q$. If the zygote divides almost longitudinally, then from the cel $y b$, two derivatives form - an upper $v$ and a lower $w$ one. However, if the zygote divides longitudinally, the $x b$ and $y b$ cells form after transverse division 2 derivatives. From cell $x b v_{1}$ and $w_{1}$ and from cell $y b-v_{2}$ and $w_{2}$ differentiate.

In spite of the rather wide differences in embryo development in various Delphinium species, there exist between them certain similarities. Embryos in ripe seeds have in all species straight lobe-like cotyledons between which lies in the form of a small apex the primordium of the shoot meristem. In the proembryos the complex of epiphyseal cells differentiates at almost the same time as does dermatogen. At the moment when dermatogen begins to differentiate, a body of cells forming the plerome can be distinguished. The apical root meristem shows an open structure.

The notions of homogeneous and nonhomogeneous layer and of proximal layer have been introduced in the present paper. As homogeneous layer is denoted in the embryo such a layer which arose from one cell of the proembryo as the result of transverse division, e.g. layer $m$ in $D$. staphisagria (Plate Fig. 2). The nonhomogeneous layer is a layer arising owing to two or more divisions e.g. the layer $m+n$ in D. tricolor (Plate Fig. 12), composed of cells which are not sisters or of their derivatives. The apical nonhomogeneous layer of the embryon formed of cells which are not sisters or of their differentiated derivatives resulting from several divisions is itermed the proximal layer, e.g. the layer $m+c a$ in $D$. cariopetalum (Plate, Fig. 16) and layer $x a+y a$ in D. tatsinense (Plate, Fig. 23).

In the examined Delphinium species all theoretically possible types of zygote division can be found. Between the 4 embryonomic groups distinguished by the author in Delphinium essential differences occur associated with the direction of zygote division. After transverse division, already in the primary stages of development of the embryo, a close relation is 
noted between division and the early differentiation of certain areas. In oblique division and, particularly, almost longitudinal or vertical division these areas appear later. The delay in differentiation of the proembryo along the axis is noticeable in an early period of development. In D. staphisagria (group I) - transverse division of the zygote - the tetrad is 2-layered. The hypophysis forms from layer $\mathrm{n}$ differentiated in the $3 \mathrm{rd}$ cell generation. In D. tricolor (group II) - oblique division of zygote the tetrad is composed of two and one half layers. The hypophysis arises from layer $o$ in the 4 th cell generation. In D. tatsinense (group IV) almost longitudinal or vertical zygote division - the tetrad is usually 2-layered. The hypophysis differentiates as late as in the more than 10-cell old proembryo.

\section{DISCUSSION}

L e b è q u e (1952) suggests that evolutionally most progressive is the type of embryo development in which the hypophysis and particular tissues and organs are earlier differentiated. If we accept this suggestion, it would seem that all the Delphinium species in which a longitudinal division of the zygote occurs are more primitive as regards embryonomic features than the species in which the zygote divides obliquely or transversely. Species in which the latter type of division occurs would be most progressive.

To data the embryonomy of only some few species of the genus Delphinium is known (B a b i s, 1973b, 1974, 1976)). $\mathrm{H} \mathrm{u}$ th (1895) distinguishes within the genus Delphinium the subgenera Consolida and Eudelphinium. In the subgenus Consolida up till now only transverse zygote division has been found, and according to this, it would seem that this subgenus comprises species which as regards embryonomic features are evolutionally more progressive than the species of the subgenus Eudelphinium. The same is indicated by the morphology of the flowers and the annual life span of plants belonging to the subgenus Consolida.

None of the so far known genera exhibits such a far going differentiation as regards embryonomic features as does the genus Delphinium.

The author is indebted to professor H. Teleży ński for his guidance and valuable advice in connection with the investigations performed and here presented.

\section{REFERENCES}

B a b is H., 1966. Embryo development in Delphinium cardiopetalum D. C. Genetica Polonica 7 (3-4): 137-151.

$\mathrm{Babis}$ H., 1973a. A new method for embedding individual objects in paraffin plugs. Genetica Polonica 14 (1): 21-28. 
B a bis H., 1973b. General description of a mature ovule and embryo sac, early stages of development of the endosperm and of embryo development in some species of Delphinium L. genera. Genetica Polonica 14 (1): 29-36.

B a bis H., 1974. Morphological classification of tetrads occuring in Delphinium L. genus - variation in their structure. Genetica Polonica. 15 (1-2): 7-12.

Babis H., 1976. Early stages of embryo development of Delphinium belladonna (Kelw.) Bergmans and philogenesis of this species. Genetica Polonica, in press. $\mathrm{Huth}$ E., 1895. Monografie der Gattung Delphinium. Bot. Jahrbuch. 20: 322-499.

J o h a n s en D. A., 1950. Plant Embryology. Chronica Botanica Company. Waltham, Mass.

L e bẹ̀que A., 1952. Recherches embryogeniques sur quelques Dicotylédones Dialypétales. Ann. Sci. Nat. Bot. ser. II. 12: 1-160.

Ly Thi Ba., 1962. Developpement de l'embryon chez le Delphinium consolida L. C. R. Acad. Sci. Paris 254 (5): 905-907.

S o u èg es R., 1910. Recherches sur l'embryogénie des Renonculacées. Bull. Soc. Bot. France 57: 242-250, 266-275.

S o u èg es R., 1911. Recherches sur l'embryogénie des Renonculacées. Bull. Soc. Bot. France 58: 542-549, 629-636, 718-725.

Sou èges R., 1912. Recherches sur l'embryogénie des Renonculacées. Bull. Soc. Bot. France 59: 23-31, 474-482, 545-550, 602-609.

S o ù̀ g e s R., 1913. Recherches sur l'embryogénie des Renonculacées. Bull. Soc. Bot. France. 60: 237-243, 283-289, 506-514, 542-549, 615-621.

Sou éges R., 1937. Embryogénie des Dipsacées. Developpement de l'embryon chez le Scabiosa succisa L. C. R. Acad. Sci. Paris. 204: 292-294.

S o u èg es R., 1938. Embryogénie des Boragacées. Developpement de l'embryon chez le Lycopsis arvensis L. C. R. Acad. Sci. Paris. 207 (15): 640-642.

S o ù̀g es R., 1941a. Embryogénie des Boragacées. Developpement de l'embryon chez le Symphytum officinale L. C. R. Acad. Sci. Paris. 212 (5): 245-246.

S o u èg e s R., 1941b. Embryogénie des Tiliacées. Developpement de l'embryon chez le Tilia platyphyllos Scop. C. R. Acad. Sci. Paris. 212 (23): 998-1000.

S o u è g e s R., 1948. Embryogénie et classification. Essai d'un système embryogénique. Partie speciale: Première période du système. Herman et co. Paris.

S o u è g e s R., 1957. Embryogénie des Dipsacées. Developpement de l'embryon chez le Scabiosa columbaria L. C. R. Acad. Sci. Paris 245: 465-468.

Srivastaw a R. K., 1952. Contribution to the embriology of Indian Euphorbiaceae. I. Euphorbia rothiana Spreng. Ann. of Bot. 16 (64): 505-511.

Author's address:

Dr Henryk Babis

Pereca Str. 2 m. 526, 00-849 Warszawa, Poland

Rozwój zarodka u niektórych gatunków rodzaju Delphinium L.

Streszczenie

U przebadanych 10 gatunków Delphinium stwierdzono wszystkie możliwe teoretycznie typy podziału zygoty - poprzeczny, skośny mocno skośny i podłużny. Z podziałami tymi związany jest szczególny, charakterystyczny sposób różnicowania się 
ciała zarodka. Embriogeneza dwóch gatunków, tj. D. tricolor i $D$. cardiopetalum wykazuje szereg prawidłowości, na podstawie których można wyodrębnić nowe typy rozwoju zarodka wśród okrytonasiennych. Typy te zostały nazwane: Valerianad i Ranunculad.

Prawdopodobnie wszystkie te gatunki Delphinium, u których występuje podłużny podział zygoty, są bardziej prymitywne pod względem cech embrionomicznych ods gatunków, u których podział zygoty jest skośny lub poprzeczny. 